
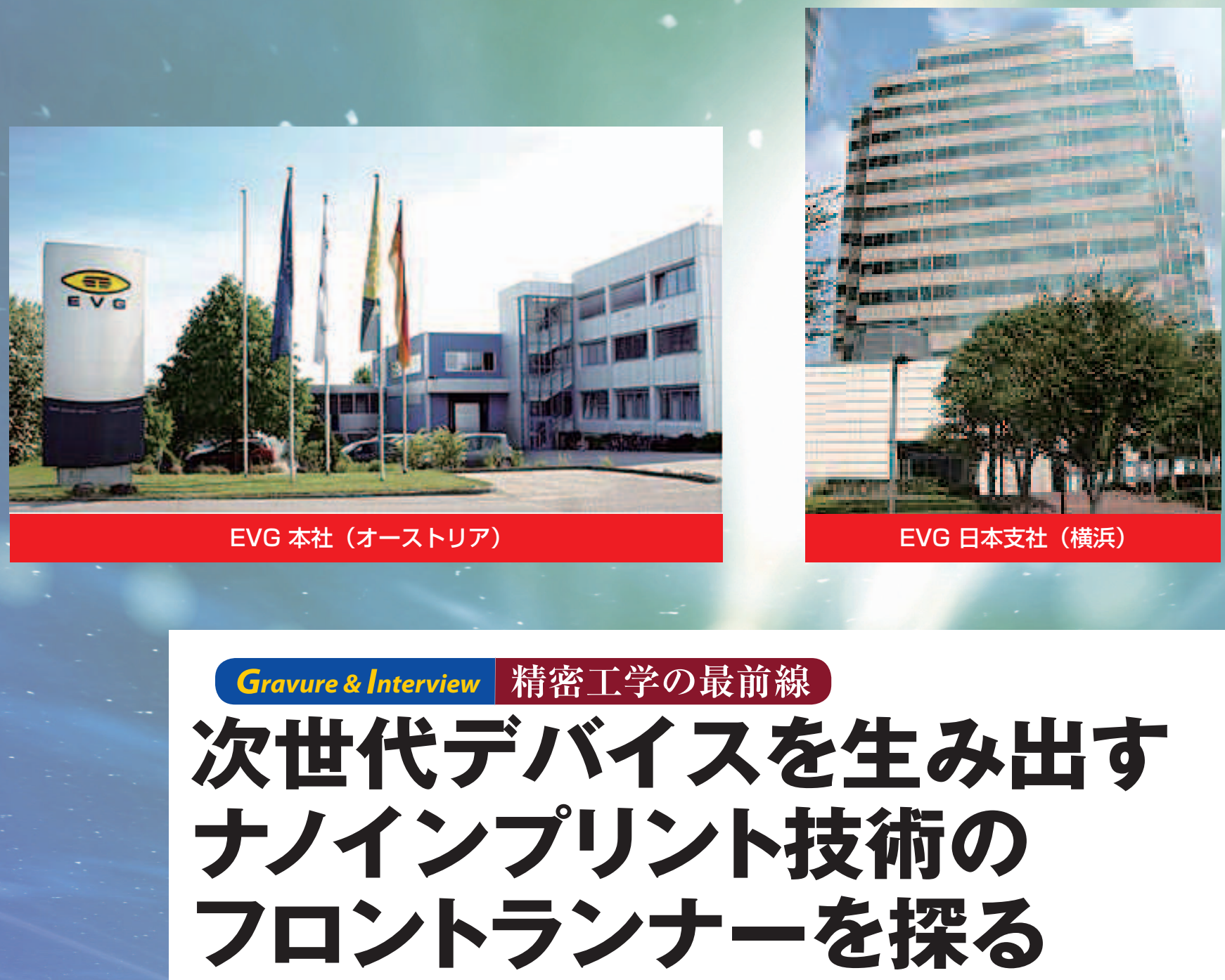

EV グループ 日本支社

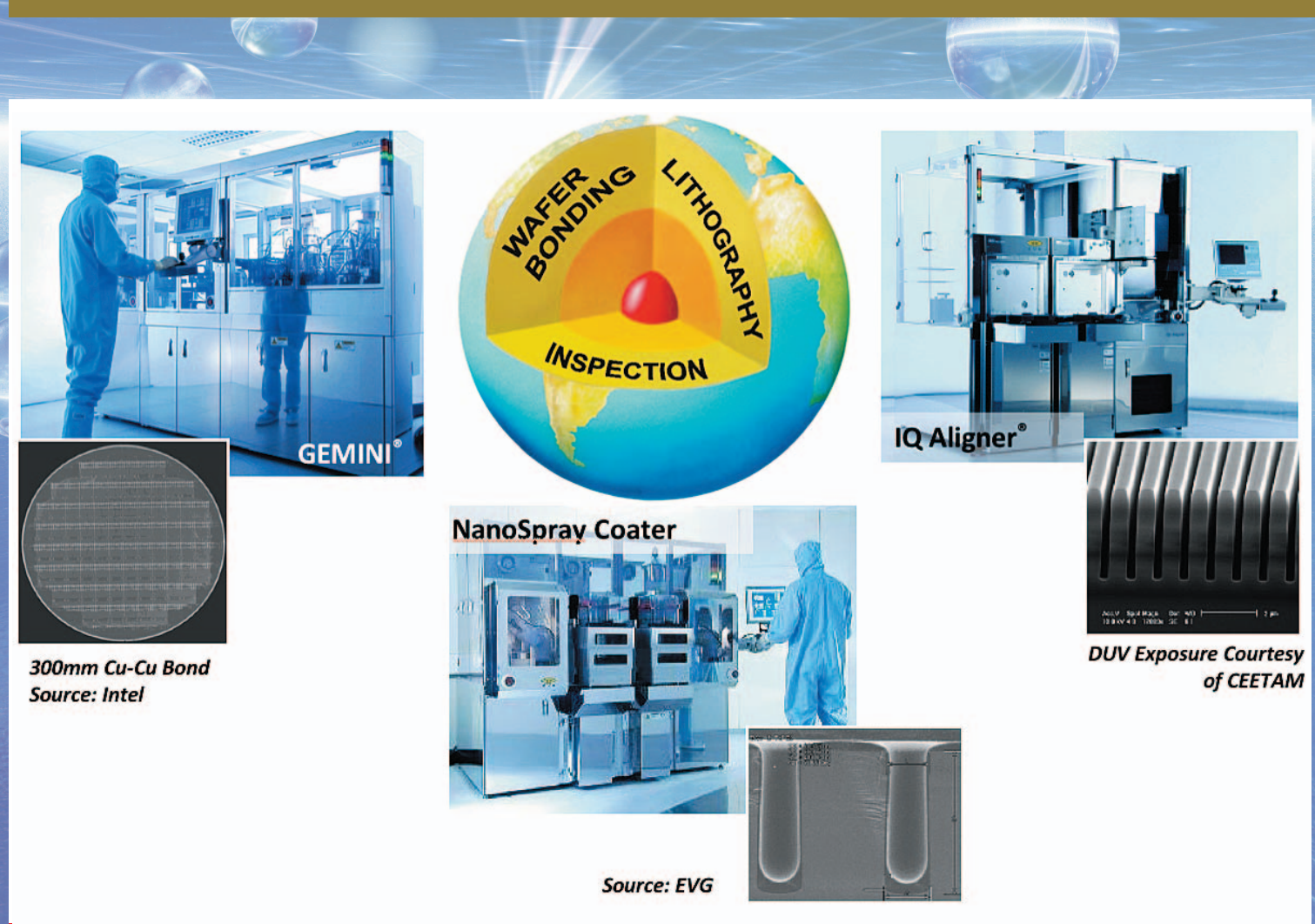

EVG のコアコンピタンスと主要製品 


\begin{tabular}{|c|c|c|c|}
\hline & Technology & $\begin{array}{l}\text { EVG Equipment for the following } \\
\text { process steps }\end{array}$ & $\begin{array}{l}\text { EVG equipment } \\
\text { platform }\end{array}$ \\
\hline 3. & Bonding & $\begin{array}{l}\text { Single wafer cleaning } \\
\text { Plasma activation } \\
\text { Precision alignment } \\
\text { Wafer bonding } \\
\text { Chip-to-wafer bonding } \\
\text { SOI Bonding } \\
\text { Temporary bonding and debonding } \\
\text { Dry film lamination }\end{array}$ & $\begin{array}{l}\text { EVG300 } \\
\text { EVG810 } \\
\text { EVG600, SmartView } \\
\text { EVG500 } \\
\text { EVG540C2W } \\
\text { EVG850 } \\
\text { EVG850 } \\
\text { EVG820 }\end{array}$ \\
\hline$\pi$ & Lithography & $\begin{array}{l}\text { Spin and spray coating } \\
\text { Bake } \\
\text { Precision aligned proximity exposure } \\
\text { Single wafer develop } \\
\text { Nanoimprint lithography (NIL) } \\
\text { Dry film activation }\end{array}$ & $\begin{array}{l}\text { EVG100 } \\
\text { EVG100 } \\
\text { EVG600, IQ Aligner } \\
\text { EVG100 } \\
\text { EVG NIL } \\
\text { EVG820 }\end{array}$ \\
\hline 19 & Inspection & $\begin{array}{l}\text { IR inspection of bonded wafers } \\
\text { Double side alignment inspection }\end{array}$ & $\begin{array}{l}\text { EVG20 } \\
\text { EVG40 }\end{array}$ \\
\hline & & EVG の製品群 & \\
\hline
\end{tabular}


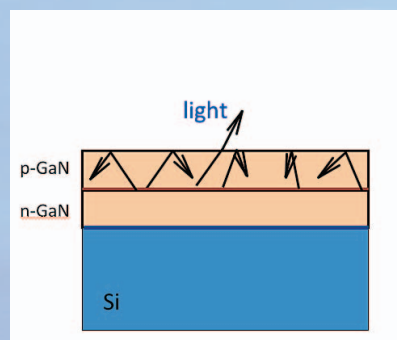

Conventional method

$\rightarrow$ Lower light intensity

$>$ Planer top surface

$>$ Large potion of light reflected back

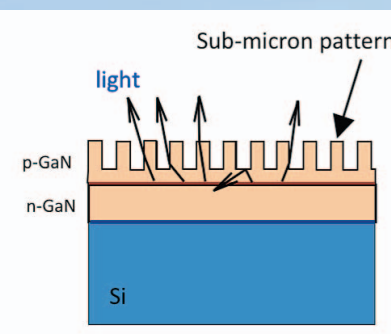

Nano-imprinted pattern on GaN $\rightarrow$ Higher light intensity

$>$ Patterned top surface

$>$ Few light reflected back

$>$ Higher brightness

\section{ナノインプリント技術を応用した高輝度 LED}
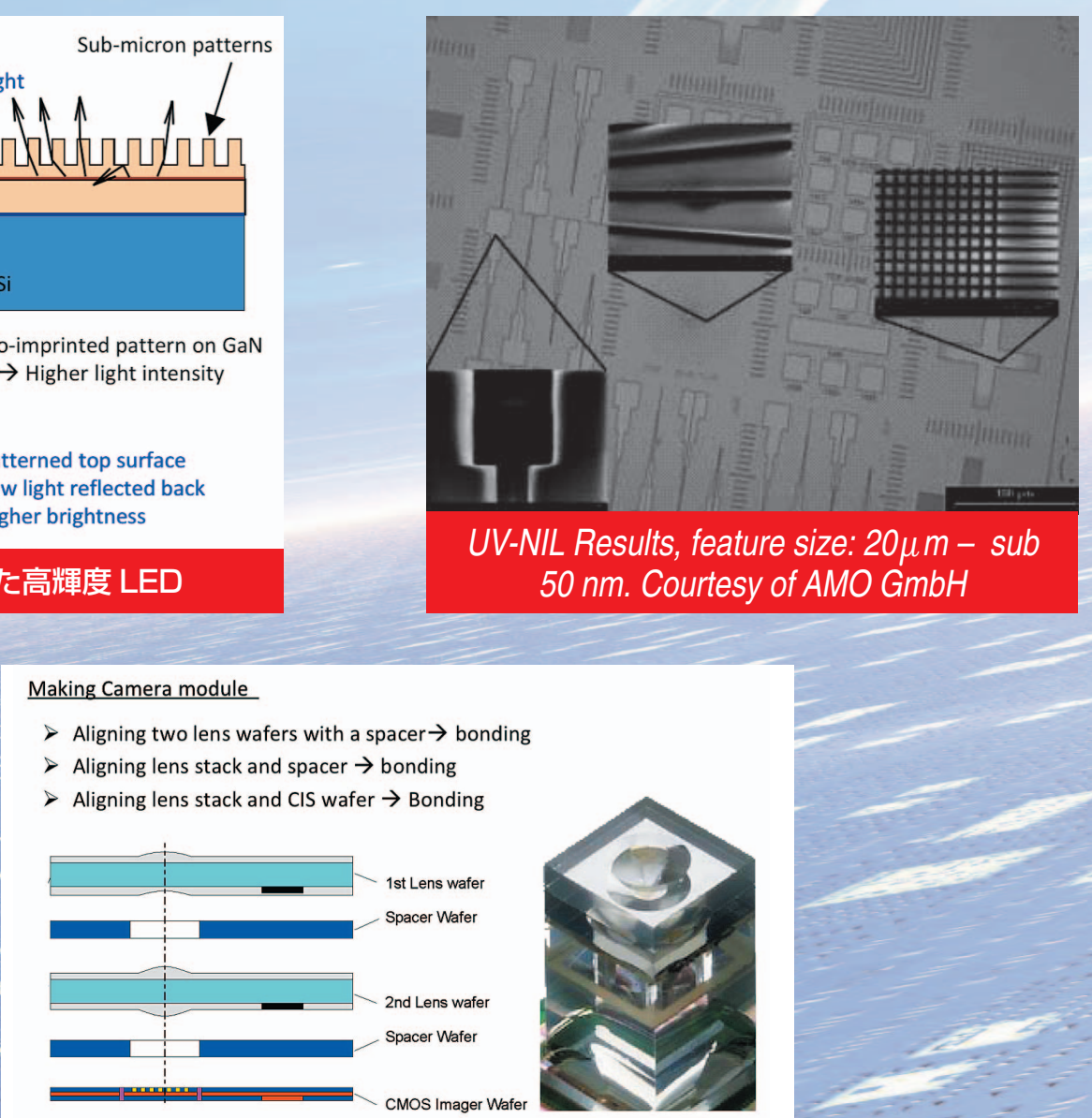

ナノインプリント技術を応用したカメラモジュールの マイクロレンズファブリケーション 
今回は, ナノインプリント装置におい て世界的シェアを有する EV グループ 日本支社（神奈川県横浜市保土ヶ谷区） を訪問し, 本号のテーマであるナノイン プリント技術や装置について, テクノロ ジ本部ディレクタであるスニル・ウィ クラマナヤカ氏にお話を伺いました.

Q 最初に御社の沿革と現在の状況に ついて教えてください.

$\mathrm{EV}$ グループ（以下， EVG. 旧名: Electronic Visions）は, 1980 年 Eric Thallner, Maria Thallner 夫妻により 設立されました。1985 年，世界初裏 面顕微鏡による両面マスクアライナを 開発. 1990 年に世界初のウエハボン ディングシステムを開発し，その方式 が業界標準になりました。その後，ア ライナ，ボンダ，コータ，剥離装置等 の商品群を展開しています。

売上規模につきましては，私企業の ため公表しておりません。

本社は, オーストリア，セントフ ロリアンにあり, 従業員約 320 名で, R\&D と製造を行っています。

オーストリア本社に加え，プロセス R\&Dの拠点は，USアリゾナ州およ び日本にあり，その他，韓国に支社， 台湾（EVG-Jointech）に現地企業との 合弁による営業拠点を置いています。 World Wide で従業員は約 400 名にな ります.

Q 御社の企業理念，目指す姿につい て教えてください.

EVG は「マイクロおよびナノ製造 技術の次世代アプリケーションにおい て，新技術のパイオニアとしての役割 を果たす」ビジョンの下，新しい商品 実現を支援するというものです

企業理念としては, Triple I - The key to your success (Invent, Innovate, Implement）を掲げています

\section{次世代デバイスを生出すナノインプリント技衙のフロントランナーを堔る}

\section{EV グループ 日本支社}

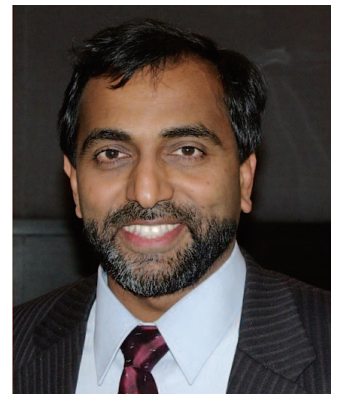

EVG Japan KK テクノロジ本部 デイレクタ

スニル ウイクラマナヤカ氏

インタビュア

富士通株式会社 西山 秀作

ロ絵グラビア参照

Q 御社の事業ドメインと主要製品群 について教えてください.

主要製品は, ウエハボンダ，マスク アライナ, コーティング装置, 仮貼り 合せ/剥離装置, 洗浄装置です。

主な適用分野は, SiP (System in Package) 等の最新半導体パッケージ (三次元実装) で，後工程に特化して います。その他にSOI 直接接合, 化 合物半導体の $\mathrm{Si}$ 接合, MEMS 製造分 野への装置を供給しています.

2008 年において World Wide で延 ベ 1400 台が稼働しております。そ の分布は, $\mathrm{EU}$, 北米, アジアでほぼ 1/3ずつであり，日本で 165 台が稼働 しています

また, 2003 年から 2008 年の 6 年連 続で VLSIリサーチ社のベストサプラ イヤ賞を受賞しております。

Q それでは，本特集の主題であるナ ノインプリント技術および装置の御社 における位置付けを教えてください.

ナノインプリントは, EVGのコア コンピタンスを基に，新たなアプリ ケーションを生み出し, 新しい事業領 域を拓いています。

特に， $\mu$-TASに代表されるバイオ メディカル分野のデバイスとマイクロ 光学素子は実用化段階のアプリケー
ションと考えています.

中でも, マイクロ光学素子への応用 は, 携带電話等のカメラモジュールと 高輝度 LED という，大規模な生産数 が期待できる製品の製造プロセスとし て完成しており, 適用への最終開発段 階にあります。

Q ナノインプリント技術には，大き く分けて熱インプリントとUV インプ リントがありますが, どのように工法 選定しているのでしょうか.

主に，精度が判断基準と考えます 熱インプリントは転写成形時に加熱— 冷却サイクルが必要となります。その ため, 温度変化に伴う膨張 - 収縮が不 可避であり，一般的に精度が低くなり ます。さらに，転写成形のための加圧 力が必要で, 高剛性の装置が必要にな ります

一方, UVインプリントは低粘度の 光硬化樹脂を使用し，光で硬化させる ため, 温度変化が少なく高精度の転写 成形が可能です。樹脂の粘度も低いた め転写成形時には $100 \mathrm{~N}$ 程度の力で成 形できるため，マスクアライナをべー スとした位置決め精度の高いインプリ ント装置が使用できます。

Q ナノインプリント技術は，装置以 外にもモールド，樹脂材料，プロセス 
条件等の技術開発が不可欠です．御社 の取組みやそれぞれの技術の勘所を教 えてください.

第一にモールドが重要です，成形の 基本単位となりますが，大面積のもの はたいへん高価です，そのため製造性 や成形法 (Step \& Repeat 等) とから その仕様が決まります.

次に, 樹脂材料が大きな要因です. 半導体デバイス用の樹脂材料と光学デ バイス用の樹脂材料では自ずと求めら れる機能が変わってきます。マイクロ 光学素子への適用では，これまで光硬 化樹脂の光学的機能（透明性, 経年変 化による黄変等）の課題があるといわ れてきましたが，現在では，十分製品 機能や寿命を満たす樹脂材料が市販さ れています。日本支社におけるアプリ ケーション開発では日本メーカの樹脂 材料を使用しています。

しかし, EVGでは, アプリケーショ ン開発は主にお客様の開発領域である
と考えており, 必要なプロセス, 技術 および装置を開発から提案すること で，その製品開発を支援することを主 眼に置いています。

Q 一方, 半導体デバイス製造におい ては, コストの要求からウエハの大型 化が進んでいます. 大型ウエハへ対応 するための技術的ポイントについて教 えてください.

次世代ウエハとして $\phi 450 \mathrm{~mm}$ への 対応が必要ですが, 早くとも5〜10 年先の技術と考えています。型化対 応と同時に, 新しいアプリケーション に対応する開発も進めています。

Q 最後に, ナノインプリント技術の 今後の展開について, 御社の考えを教 えてください. また, 日本市場につい ての考えを教えてください.

前述したように, マイクロ光学素子
の製造をビジネスとして軌道に乗せる ことを最優先に取り組んでいます。特 に，ウエハ接合技術をベースにしたカ メラモジュールのウエハファブリケー ション工法は, カメラモジュールの低 価格化をさらに推し進める技術です.

高輝度 LED や MEMS センサは, 技術は日々進歩していますが, 市場と していまだ成長していないと考えてい ます。これらの分野は，日本が技術的 に先行しており，それを支援すること がビジネスである EVGにとって日本 支社は重要な地位にあると考えます.

一方, バイオメディカル分野への応 用は市場が形成されるかどうかは混沌 としており, 今後の課題といえます.

本日は, お忙しい中, 興味深いお話を 聞かせていただき，ありがとうござい ました.

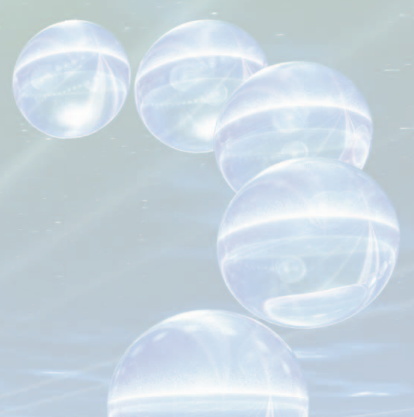

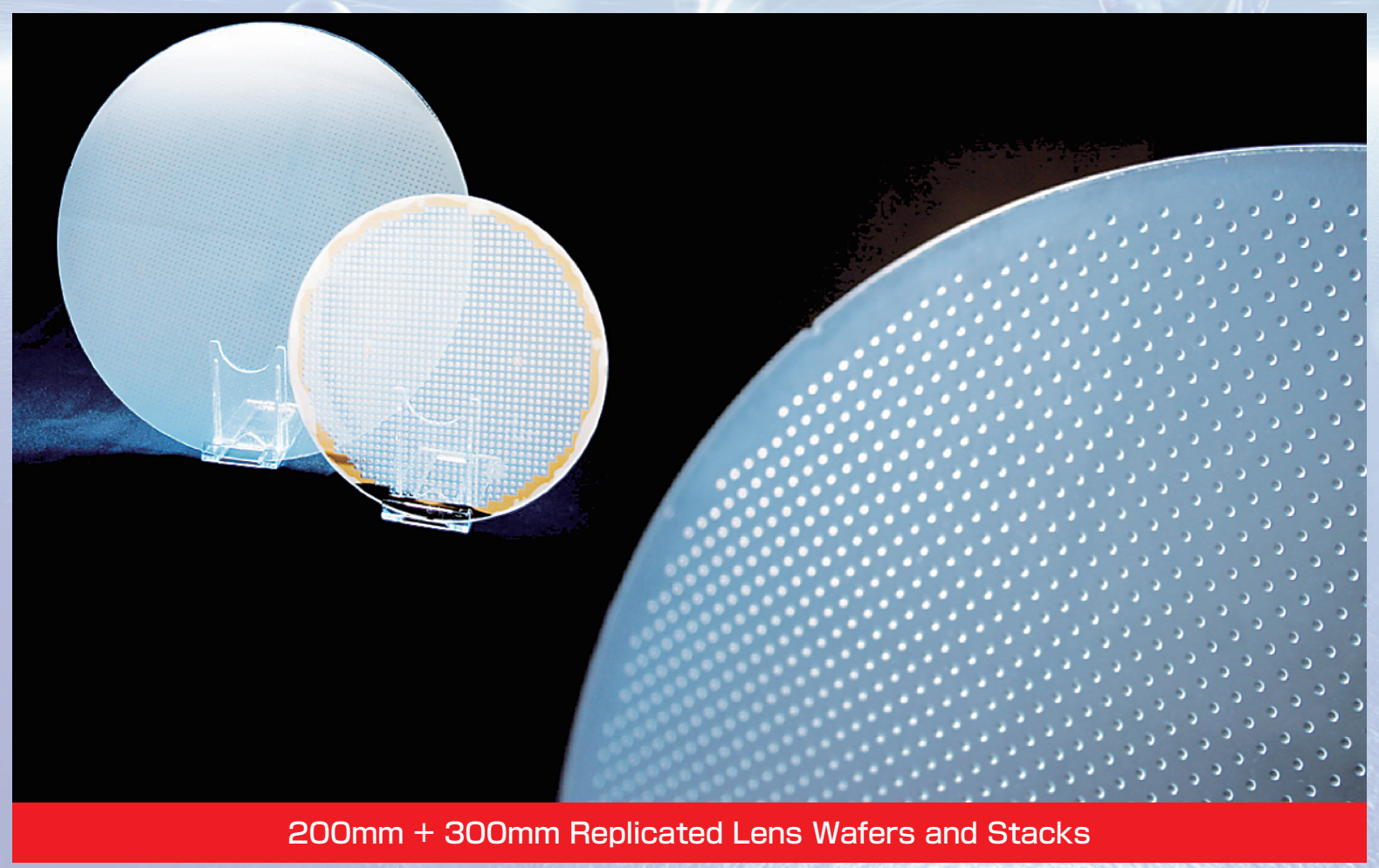

